\title{
OPTIMAL DISTRIBUTION OF PRODUCTION TASKS IN A CONCERN
}

Stefan Grzesiak, Ph.D., Associate Prof.

University of Szczecin

Faculty of Economics and Management

Department of Operations Research and Applied Mathematics in Economics

Mickiewicza 64, 71-101 Szczecin, Poland

e-mail: stefan.grzesiak@usz.edu.pl

Received 20 December 2016, Accepted 21 March 2017

\begin{abstract}
The problem of the optimal distribution of production tasks within a large business entity (a concern, a corporation) is discussed in this paper. The fundamental aim is to determine such a distribution of production tasks that minimizes total production costs. For this purpose the author proposes an approach that takes into account Lagrange multipliers. The author formulates the conditions for the application of such an approach and the option of its possible application in practice.
\end{abstract}

Keywords: production distribution, method of Lagrange multipliers, cost minimization

JEL classification: C44 


\section{Introduction}

The problems related to decision-making that frequently occur in practical applications include the long-standing issue of production task distribution. Seemingly it is a well-known problem that has already been resolved, since its origin dates back to the beginnings of operations research. In later years many authors made attempts at reformulating and solving this classic problem. ${ }^{1}$ It can be analysed in a variety of ways. One of which is task scheduling, when particular production process stages are performed in sequence. Then the main issue comes down to determining a proper sequence of the operations performed in particular production places in the same or in related enterprises. Such significant terms as production tasks and production places require a precise definition. Production tasks or products may mean, e.g. machine parts, which are subsequently assembled into one whole, various types of a manufactured product, specific work performed, e.g. excavations, etc. When defining production places we take into account manufacturing devices (excavators, machine tools, machining cell, etc.).

Alternative approaches on the discussed problem come to the assignation for example of the most advantageous structure of production of specific finished goods to maximise it or fully execute the contract. In the last 20-30 years authors seem to have been avoiding the abovementioned problem. Techniques of production organisation based on the assembly from the subassemblies of finished goods became so popular that the classical approach stopped being significant. The main role was assigned to operational management, in which the production planning in the context of analysis of production capabilities, creation of the main production plan and control of the production process have the most important meaning. The literature also proposes the use of multi-criteria programming for both planning and control of the production process. Consideration on this subject can be found in works by: M. Nowak (2015), T. Loukil, J. Teghem, D. Tuyttens (2005) and W. Sikora (2008).

Not denying this important direction of research, it should be noted that in some cases other accents should be considered. It is worth indicating and remembering the approach, in which the most advantageous distribution of the final production between technologically independent units with a common decision centre is possible.

A slightly different train of thought was presented in this paper, which resulted from the assumptions presented below.

The problem raised in the paper refers to the way of determining possibly the most beneficial distribution of final production among manufacturing entities that constitute a conglomerate

\footnotetext{
1 The works of Lange (1967), Hellwig (1972), Kryński, Badach (1976), Kantorowicz, Gorstko (1976), Kruszewski, Szwiecow (1979), Czerwiński (1980) and Radzikowski (1997) may be cited.
} 
bound chiefly by financial ties and sharing a common decision-making centre. The assumption is to refer to it as a concern in the paper. ${ }^{2}$

A concern or a corporation fundamentally groups a multitude of enterprises which are tied organizationally, financially or through production. In such cases it is necessary to develop ways of cooperation or joint task performance. A particular type of such operation involves the fulfilment of partial production tasks, whose effect is important to the entire concern. We assume that a certain set of products is manufactured which can be fabricated in different enterprises constituting a concern. We assume that the manufacturing of particular types of goods, whose production can be performed in all or in certain enterprises forming a concern, constitute production tasks. It is self-evident that specific tasks can be performed differently in each enterprise being a part of a concern on account of natural conditions, technical preparation and staff capacity. We also assume that it is impossible to concentrate the entire executed order in one entity, which consequently results in the need to distribute it among individual contractors. Therefore, selecting them appropriately becomes crucial. The manner and criteria of selecting participants remain a decision-related issue, which can be resolved through the use of models and methods of operations research.

These are the issues that the presented paper is devoted to. The subject matter that the author has focused on is such diversification of the afore-mentioned production tasks that enables the execution of a designated task and at the same time achieving possibly the most favourable economic effect.

\section{Formal presentation of a decision-making process}

Let it be assumed that within a time period of $T$ (e.g. one year) a certain concern is to manufacture $Q_{i}(i=1,2 \ldots, r)$ product units of $i$ type. $N$ number of enterprises operates in the concern, each of which can manufacture several types of those products. The enterprises have limited production capacity; however, they are large enough to be capable of fabricating an assigned production volume within a given timeframe. Let it be further assumed that for each enterprise the functions of production costs are known, defining individually their dependence on the production scale of particular products. Only variable production costs will be considered, since fixed production costs will not have an impact on the final optimal solution. For simplicity's

\footnotetext{
2 There is no point in discussing which of the terms - a concern, a corporation or others - is the most adequate. Symbolically any of the terms can be adopted. In the paper we will use the term 'a concern'.
} 
sake, let us assume that it is mass production to such a degree that the production can be treated as a continuous process.

Considering the production capacity of individual enterprises, we will introduce the socalled uncertainty coefficients into the deliberations. That is how we will refer to continuous variables that enable detecting different production capacities related to the natural conditions of individual enterprises. For a company operating in typical conditions it will be around one, and in enterprises of worse than average production conditions it will be below that value, whereas in better ones, companies may have a coefficient measuring more than one. Let us also assume that the probability distribution or density functions of the coefficients are known. ${ }^{3}$

In the form proposed above the matter of production distribution can be presented in the following way:

$$
K=\sum_{i=1}^{r} \sum_{j=1}^{n} f_{i j}\left(x_{i j}\right)+\sum_{i=1}^{r} b_{i}\left(Q_{i}-\sum_{j=1}^{n} x_{i j} \varphi_{i j}\right) \rightarrow \min
$$

adopting the following conditions:

$$
\begin{gathered}
\sum_{j=1}^{n} \sigma_{i j}^{2} x_{i j}^{2} \leq A_{i}, \quad i=1,2, \ldots, r \\
\sum_{j=1}^{n} \varphi_{i j} x_{i j}=Q_{i,}, \quad i=1,2, \ldots, r \\
x_{i j} \geq 0, \quad j=1,2, \ldots, n, \quad i=1,2, \ldots, r
\end{gathered}
$$

Explanations:

$n-$ number of enterprises belonging to a concern,

$r \quad-$ number of products manufactured in a concern,

$x_{i j} \quad-$ production volume of $i$ product in $j$ enterprise,

$f_{i j}\left(x_{i j}\right)$ - the function of production cost of $i$ product in $j$ enterprise,

$b_{i} \quad-$ the cost of an entity's shortage of $i$ product, incurred by a concern,

$Q_{i} \quad-$ planned production volume of $i$ product in a concern,

$\varphi_{i j} \quad-$ uncertainty coefficient for $i$ product in $j$ enterprise,

$\sum_{j=1}^{n} x_{i j} \varphi_{i j}-$ expected production volume of $i$ product in all of the enterprises,

$\sigma_{i j}^{2}-$ variance of $\varphi_{i j}$ variable,

$\mathrm{A}_{i} \quad-$ top limit of production fluctuation risk.

\footnotetext{
3 The significance and the justification of the coefficients existence was discussed by, inter alia, O. Lange in his works (1967).
} 
Criterion function (1) is composed of two parts. The first one comprises the production costs of individual products in enterprises, depending on production volume. The second one expresses the possible costs related to the too low production scale of certain products. Considering the existence of an uncertainty coefficient, it is generally possible for such a situation to take place. Unit costs of a shortage may result from the necessity to import certain products or paying contractual penalties to contractors. The costs of the emergency start of the manufacture of products of a substitutive nature may arise as another component. If a production surplus is generated, which can be favourably managed, then component $b_{i}\left(Q_{i}-\sum_{j=1}^{n} x_{i j} \varphi_{i j}\right)$ will obviously be negative, which would mean a cost reduction. The limitations (2) arise from the following train of thought. What is important is the certainty that a concern may expect deliveries from other companies. The higher the production fluctuation is, the less certain the receipt of the assumed product volume becomes. The risk related to the production fluctuation of $j$ enterprise regarding $i$ product can be measured through the variance of a possible shortage:

$$
D^{2}\left(Q_{i}-\sum_{j=1}^{n} x_{i j} \varphi_{i j}\right)
$$

With the assumption that $\varphi_{i j}$ variables are independent, the following can be assumed:

$$
D^{2}\left(Q_{i}-\sum_{j=1}^{n} x_{i j} \varphi_{i j}\right)=D^{2}\left(Q_{i}\right)+\sum_{j=1}^{n} D^{2}\left(x_{i j} \varphi_{i j}\right), \quad i=1,2, \ldots, r
$$

From the corresponding theorems of a probability calculus, we eventually arrive at:

$$
D^{2}\left(Q_{i}-\sum_{j=1}^{n} x_{i j} \varphi_{i j}\right)=\sum_{j=1}^{n} x_{i j}^{2} D^{2}\left(\varphi_{i j}\right)=\sum_{j=1}^{n} x_{i j}^{2} \sigma_{i j}^{2}, \quad i=1,2, \ldots, r
$$

Expression (7), presenting the variations of shortages for individual products, should not exceed a risk fluctuation pre-determined for them. The risk, defined in value $A_{i}$, constitutes the limit we would be prepared to accept in the course of the production planning process. Limitations (3) are equivalent to the assumption that production order fulfilment should be covered only with the participation of the enterprises operating within the framework of a corporation. 


\section{Proposal for solving a decision-making process}

A solution to problem (1-4) eventually leads to determining a suitable product range for each enterprise belonging to a corporation, while the production volume is determined individually for the entire period under analysis. If it is assumed that conditions (2) can be presented in the form of the following formulae:

$$
\sum_{j=1}^{n} x_{i j}^{2} \sigma_{i j}^{2}=A_{i}, \quad i=1,2, \ldots, r
$$

then in order to solve problems (1-4) one can try applying the Lagrange multipliers method.

The Lagrange function can be presented as follows:

$$
L=\sum_{i=1}^{r} \sum_{j=1}^{n} f_{i j}\left(x_{i j}\right)+\sum_{i=1}^{r}\left[b_{i}\left(Q_{i}-\sum_{j=1}^{n} x_{i j} \varphi_{i j}\right)+\lambda_{1 i}\left(\sum_{j=1}^{n} x_{i j}^{2} \sigma_{i j}^{2}-A_{i}\right)-\lambda_{2 i}\left(\sum_{j=1}^{n} x_{i j} \varphi_{i j}-Q_{i}\right)\right] \rightarrow \min
$$

After differentiating $L$ with regard to all the variables, we arrive at:

$$
\begin{gathered}
\frac{\partial L}{\partial x_{i j}}=f_{i j}^{\prime}\left(x_{i j}\right)-b_{i}+2 \lambda_{1 i} \sigma_{i j}^{2} x_{i j}-\lambda_{2 i} \varphi_{i j}=0, \quad i=1,2, \ldots, r, j=1,2, \ldots, n \\
\frac{\partial L}{\partial \lambda_{1 i}}=\sum_{j=1}^{n} x_{i j}^{2} \sigma_{i j}^{2}-A_{i}=0, \quad i=1,2, \ldots, r \\
\frac{\partial L}{\partial \lambda_{2 i}}=\sum_{j=1}^{n} x_{i j} \varphi_{i j}-Q_{i}=0, \quad i=1,2, \ldots, r
\end{gathered}
$$

System (10-12) comprises of maximum $(n+2) r$ equations ${ }^{4}$. Its solution leads to the determination of $x_{i j}$ as well as $\lambda_{1 i}$ and $\lambda_{2 i}$ variables. Their value depends, as can easily be verified, also on the determined limits of $A_{i}$.

Since $\varphi_{i j}$ variables assume the values around one, and they typically have regular distributions, ${ }^{5}$ it may be accepted that with the assumption of $E\left(\varphi_{i j}\right)=1$, that equations (10) have the following form:

$$
\frac{\partial L}{\partial x_{i j}}=f_{i j}^{\prime}\left(x_{i j}\right)-b_{i}+2 \lambda_{1 i} \sigma_{i j}^{2} x_{i j}-\lambda_{2 i}=0
$$

\footnotetext{
${ }^{4}$ In reality the number of equations will be significantly lower, because individual enterprises do not produce all of the products manufactured in a corporation.

5 Cf. Lange (1967), pp. 193-196 and Hellwig (1972), pp. 135-136.
} 
Analysing the conditions sufficient for the existence of the minimum of the $L$ function, we find partial derivatives:

$$
\frac{\partial^{2} L}{\partial x_{i j}}=f_{i j}^{\prime \prime}\left(x_{i j}\right)+2 \lambda_{1 i} \sigma_{i j}^{2}, \quad i=1,2, \ldots, r, j=1,2, \ldots, n
$$

For the existence of the minimum, the second derivatives $\frac{\partial^{2} L}{\partial x_{i j}}>0$, whence we arrive at:

$$
\lambda_{1 i}>-\frac{f_{i j}^{\prime \prime}}{2 \sigma_{i j}^{2}}, \quad i=1,2, \ldots, r, j=1,2, \ldots, n
$$

It appears that the condition for the existence of this extremum is that $\lambda_{1 i}$ multipliers need to satisfy inequality (15).

At this point the production volume that would need to be assigned to individual enterprises can be determined. We can determine it directly from the following equations:

$$
x_{i j}=\left(2 \lambda_{1 i} \sigma_{i j}^{2}\right)\left[b_{i}-f_{i j}^{\prime}\left(x_{i j}\right)+\lambda_{2 i}\right], \quad i=1,2, \ldots, r, j=1,2, \ldots, n
$$

Formula (16) indicates that the production volume assigned to each enterprise depends on the cost of that product shortage, the end-cost of production, $\varphi_{i j}$ variable variance as well as $\lambda_{1 i}$ and $\lambda_{2 i}$ multipliers.

\section{Conclusions}

The conducted deliberations lead to a conclusion that in certain specific conditions it is possible to distribute global production tasks and in order to fulfil them at possibly the lowest cost thanks to optimal task assignments to individual entities. Obviously, it does not exhaust in full the problem under discussion, since during the deliberations e.g. the possibility of commissioning a part of the production outside of the concern was not taken into consideration, which is a fairly common practice. However, the point was to present an approach in which such a division can be executed independently. The effective possibilities of implementing the presented decision-making model constitute a separate dilemma. It is not hard to demonstrate its numerous limitations and weaknesses. One of the major ones is the need to assume the establishment of mass production, which significantly limits the sectors and types of manufactured products that can be considered. It is not easy to determine risk coefficient distributions, since it requires either available data of the course of past production, or adoption of other arbitrary assumptions. The conducted considerations have a theoretical nature and they are not directly 
useful for implementations. However, in the case of a specific concern, in which the production process would be realised with accordance to that described in the article procedure, partial cost function, and the estimation of probabilities of fluctuations could be estimated. Eventually, the trial of the assignment of optimal production distribution between manufacturing units could be taken. In this context, it seems that the presented approach is interesting and at least in some cases it could be applied in economic practice.

\section{References}

Czerwiński, Z. (1980). Matematyka na ustugach ekonomii. Warszawa: PWN.

Fredendall, L.D., Lea, B.R. (1997). Improving the product mix heuristic in the theory of constraints. International Journal of production Research, 35 (6), 1535-1544.

Hellwig, Z. (ed.) (1972). Elementy rachunku ekonomicznego. Warszawa: PWE.

Kantorowicz, L., Gorstko, A. (1976). Optymalne decyzje ekonomiczne. Warszawa: PWE.

Kruszewskij, A., Szwecow, K. (1979). Matiematiczeskoje programirowanije i modielirowanije w ekonomikie. Kijów: Wyższaja Szkoła.

Kryński, H., Badach, A. (1976). Zastosowanie matematyki do podejmowania decyzji ekonomicznych. Warszawa: PWN.

Lange, O. (1967). Optymalne decyzje. Warszawa: PWN.

Loukil, T., Teghem, J., Tuyttens, D. (2005). Solving multi-objective production scheduling problems using metaheuristics. European Journal of Operational Research, 161 (1), 42-61.

Nowak, M. (2013). An interactive procedure for Aggregate Production Planning. Croatian Operational Research Journal, 4, 247-257.

Nowak, M. (2015). Modelowanie decyzji w zarzadzaniu operacyjnym. Katowice: Wydawnictwo Uniwersytetu Ekonomicznego.

Radzikowski, W. (1997). Badania operacyjne w zarządzaniu przedsiębiorstwem. Toruń: Toruńska Szkoła Zarządzania.

Sikora, W. (ed.) (2008). Badania operacyjne. Warszawa: PWE.

Waters, D. (2001). Zarzadzanie operacyjne. Towary i ustugi. Warszawa: Wydawnictwo Naukowe PWN. 